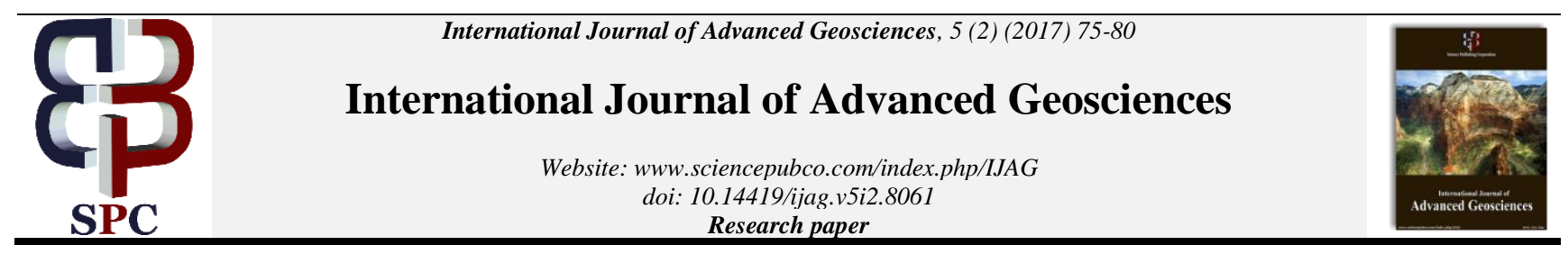

\title{
Geothermal modelling and its application to hydrocarbon generation from agbada formation. a case study of USANi field, Niger delta basin, Nigeria
}

\author{
G.O Aigbadon ${ }^{1 *}$, A, U. Okoro ${ }^{2}$. E.O. Akpunonu ${ }^{2}$. J.R. Nimnu ${ }^{2}$. A. Ocheli ${ }^{2}$ \\ ${ }^{1}$ Wesley University Science and Technology, Ondo, Ondo State, Nigeria \\ 2 Nnamdi Azikiwe University, Awka, Anambra State, Nigeria \\ *Corresponding author E-mail: godwin.aigbadon@yahoo.com
}

\begin{abstract}
The geothermal model was done with the integration of surface. Subsurface temperature's data and formation depth values from suites of well log in the study field. The well comprises Gamma-ray log (GR log), Spontaneous Potential logs (SP log), Resistivity $\operatorname{logs}$, Formationdensity, Neutron $\log$ and Sonic log. The suites of welllog within the studied sequences penetrates Agbada and the Benin Formation. The Benin Formation comprises mainly of continental sands, and the Agbada Formation consist of alternating sequence of sand and shales within the study wells. The estimated thickness and temperature values within the study field falls within the range from $1357-3500 \mathrm{~m}$ and $101^{\circ} \mathrm{C}-120.5^{\circ} \mathrm{C}$ with estimated geothermal gradient range of $\left(0.028-0.03^{\circ} \mathrm{C} / 100 \mathrm{~m}\right)$ in the field. The geo-temperatures results range of $101.60^{\circ} \mathrm{C}-119.60^{\circ} \mathrm{Cat}$ modeled depth of $1357 \mathrm{~m}-3500 \mathrm{~m}$, indicating that the shale sequence at the basal path of the Agbada Formation is thermally matured with sufficient organic matter to generate hydrocarbon in the study field as earlier believe to be immature and cannot generate hydrocarbon. The geothermal model can be applicable to any sedimentary basin in the world. This work is also an important tool in source rock evaluation to compliment petroleum geochemistry and position the hydrocarbon generating window of the study field.
\end{abstract}

Keywords: Temperature Data; Geothermal Gradient; Geothermal Modeling; Thermal Maturity; Oil and Gas Window.

\section{Introduction}

The Niger Delta is stood among the world' largest delta complexes. The sequence comprises from base to top; the Akata, Agbada and Benin Formations (Short and Stauble, 1967). The aspects of the petroleum geology of the basin are discussed in Merki, (1972), Weber and Daukoru, (1975), Evamy et. al. (1978). Generation and expulsion of hydrocarbon in relation to temperature have been discussed in Avbovbo (1978), Evamy et. al. (1978) and Ejedawe (1982). Oomken (1974) used lithofacies to interprete subenvironments within the delta. Weber (1971) discussed sedimentological aspects of oil field in the Niger Delta and described the offlap sequence of transgress-regressive sequence. He further added that sediments and sedimentary processes are contain inwell logs. Sediments in different paleo- environments display characteristic's log motifs. As a result, borehole logs are widely used to interpreted sedimentary facies (Weber, 1971). The origin of the source rock within the Niger Delta has been a matter of debate for more than a decade. Earlier works by Weber and Daukoru (1975) is of the opinion that the Agbada Formation is immature implying that the Akata Shale would have been possible source of the hydrocarbon in the Niger Delta. Migration of hydrocarbon in the Niger Delta basin is from source rock of Akata Shale (Weber and Daukoru, 1975). The migration of the hydrocarbon is through the growth fault which are numerous in the basin and actually trap hydrocarbon in structural closures within the growth fault androllover system which are the predominant structures of the Niger
Delta (Doust and Omatsola, 1990). The parallic Agabada formation is the hydrocarbon prospective sequences in the basin. It is characterized by sand, silts and shale in various proportions and thickness.

Oil and gas are formed from the remains of dead organic matter buried in sedimentary rocks at subsurface depth. The mechanisms of transformation are mainly heat and depth. The major phases are important in the conversion of rich kerogen matter in sedimentary rock to form oil and gas, which are diagenesis, catagenesis and metagenesis. Diageneses occur at shallow depth where burial of sediments are at shallow depth and surface temperature to form marsh gas (methane). Catagenesis is a process whereby at greater depth and favourable temperature above $60^{\circ} \mathrm{C}$, an organic-rich sediment can generate oil and gas ( Selley, 1996).). Metagenesis is the irreversible transformation of organic-rich sediment to graphite at greater temperatures above $225^{\circ} \mathrm{Cand}$ deeper depth of burial. It shows that temperature, time depth of burial; Pressures are important factors in the rate of maturity of kerogen.

The objectives of this work is to use the plot of formation depth against reservoir temperature from bottom hole temperatures data to produce the geothermal model of the field, evaluating thermal maturity of shale beds of the Agbada Formation and position the hydrocarbon generating window with a view of understanding the hydrocarbon prospects in the studied field. The mathematical model is also applicable to any sedimentary basin in the world. 


\section{Location}

Usani field is located at Oil Mining Lease (OML) 135, offshore Niger-Delta Basin of Nigeria Fig. (1). The Field covered a total area of $31 \mathrm{sqkm}$ off shore south western coast of Nigeria's deep water, and the base map is shown.

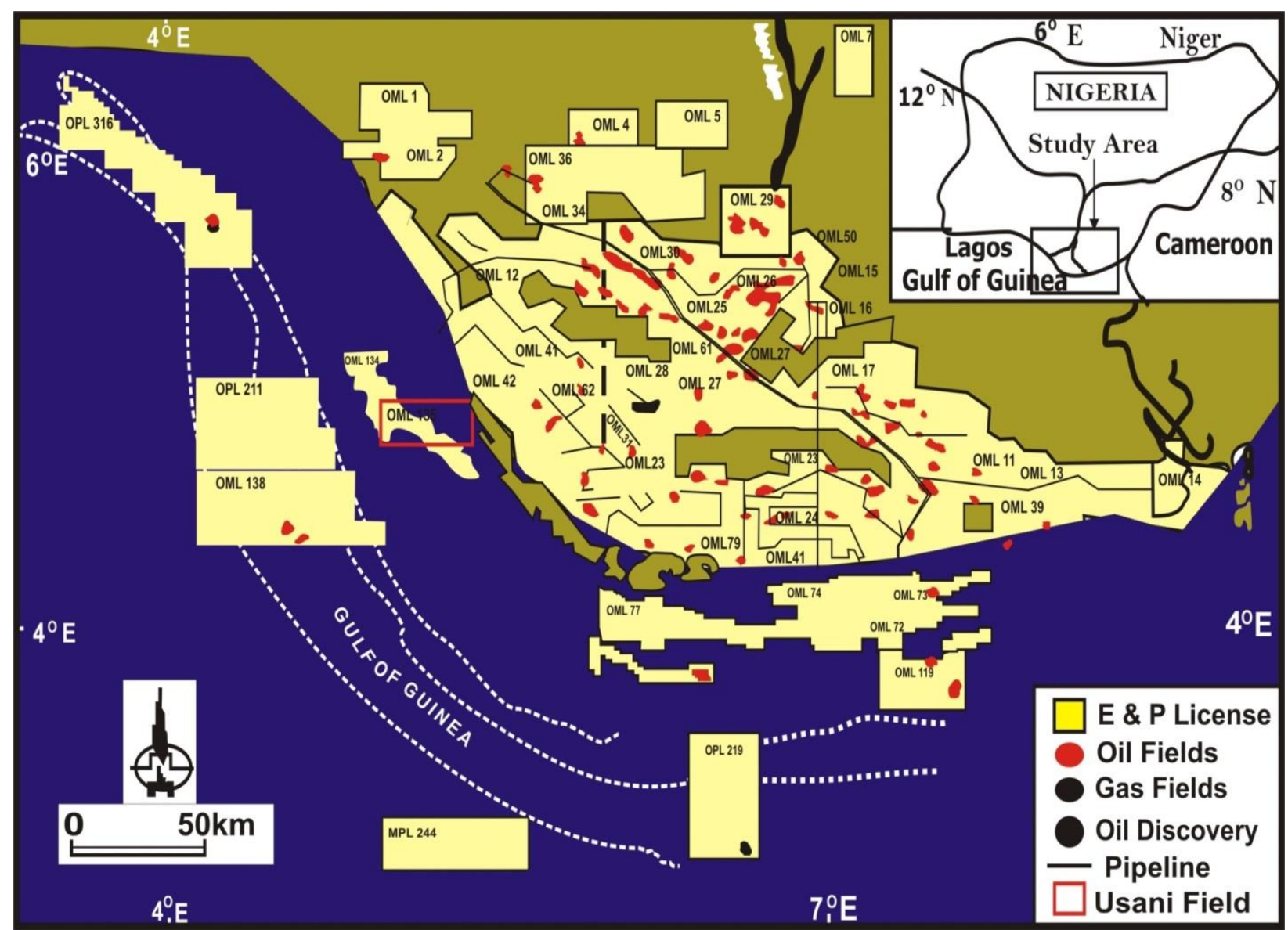

Fig. 1: Concessionmap of Niger Delta Showing Study Field (Doust and Omatsola, 1990; Aigbadon Et.Al., 2017).
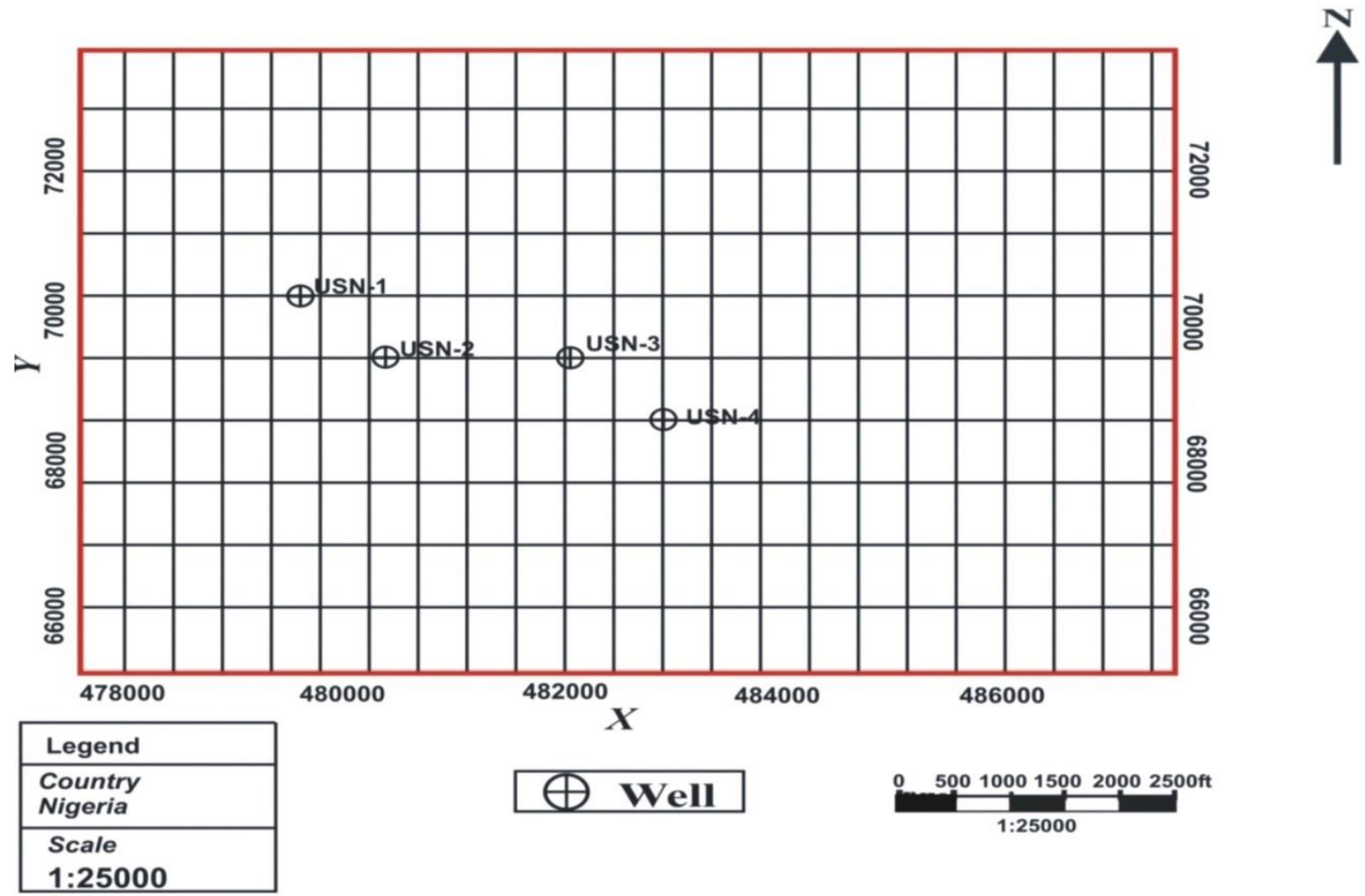

Fig. 2: Well Location Map ((Aigbadon Et.Al., 2017)). 


\section{Materials and method}

The data that was used to achieve the objectives of the study field are the GR $\log$, SP $\log$, resistivity log, caliper log and geotemperature data from Usani wells 1-4. The data are from Shell Exploration and Production Company, Port Harcourt, Nigeria with the permission of Department of Petroleum Resources (DPR), lagos, Nigeria.

\section{Correlation in the wells}
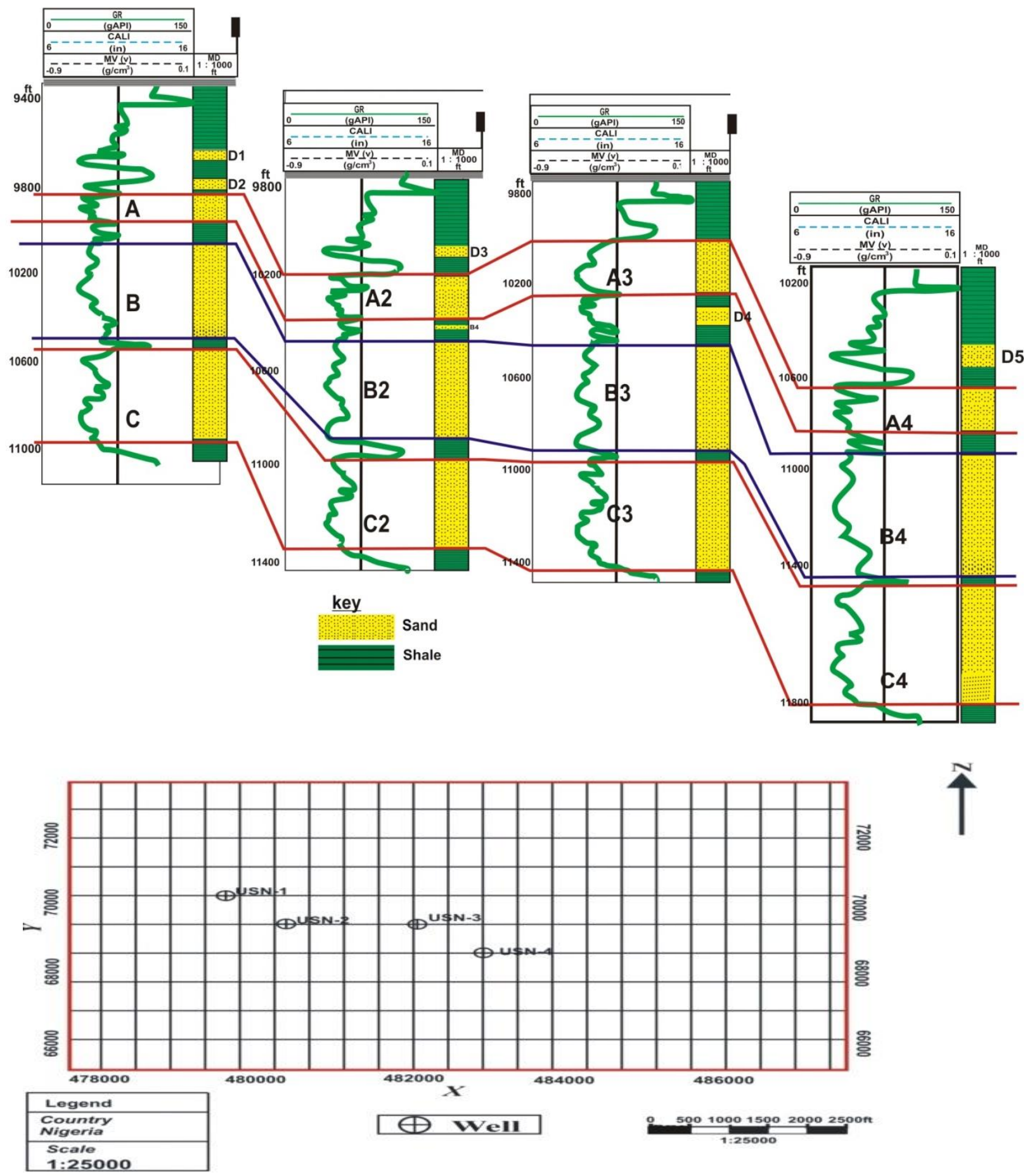

Fig. 3: Correlation in Well 1, 2, 3 And 4 in NW-SE Direction (Aigbadon Et.Al., 2017).

The lith-section were drawn to a scale of $1 \mathrm{~cm}-100 \mathrm{~m}$, (Fig.3). The quanliitative techniques were usedto determine the shales in the wells drilled. The GRlog were used to delineate litologic section of the studied intervals, and the shale units were properly delineated from the sand bodies. The correlation was done on well1, 2, 3 and 4 to map the reservoirs and shale thickness. Geo thermal equation was used to determine the thermal maturation potentials for shales intervals in the well logs because all the wells penetrated the Agbada Formation.

Geothermal Analysis of the Agbada Formation in the basin.

The geo-temperature data for the studied wells in the field are given below in table 1 
Table 1: Geo-Temperature Data for the Wells

\begin{tabular}{llll}
\hline Wells & Reservoir & $\operatorname{Depth}(\mathrm{m})$ & Reservoir temperature $(\mathrm{c})$ \\
\hline \multirow{3}{*}{1} & A & $2946-2982$ & 110.00 \\
& B & $2994-3138$ & 112.00 \\
2 & C & $3162-3293$ & 116.00 \\
& A2 & $3066-3012$ & 115.00 \\
3 & B2 & $3126-3263$ & 115.00 \\
& C2 & $3293-3413$ & 116.00 \\
& A3 & $2994-3054$ & 115.20 \\
4 & B3 & $3126-3257$ & 116.10 \\
& C3 & $3269-3434$ & 116.20 \\
& A4 & $3054-3434$ & 116.80 \\
& B4 & $3246-3341$ & 117.50 \\
& C4 & $3372-3532$ & 118.50 \\
\hline
\end{tabular}

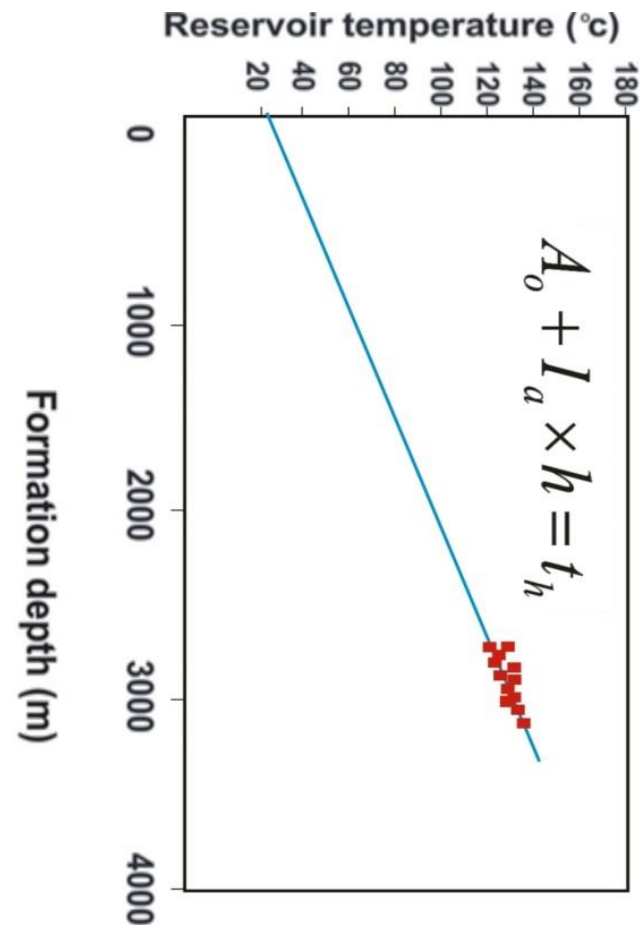

Fig. 4: Plot of Reservoir Temperature Against Formation Depth (M) in the Wells.

The plot of formation temperature against formation depth is a linear function (Fig.4). The first step for generating the hydrocar- bon maturity model is to determine the geothermal gradient (equation 1) [After Akpunonu et.al. 2012), Aigbadon et.al. , 2016)]

Geothermal gradient $(\mathrm{I})=\frac{\Delta T}{\Delta D}$

Geo-temperature Analysis

From the plot of temperature against depth

$A_{o}+I h=t_{h}$

Equation (1) can be rewritten as

$A_{o}+\frac{\Delta T}{\Delta D} \times h=t_{h}$

Simple model for positioning oil and gas windows for the field of study.

Recall

$A_{o}+\frac{\Delta T}{\Delta D} \times h=t_{h} \quad$ and $\quad I=\frac{\Delta T}{\Delta D}$

$A_{o}+I_{a} \times h=t_{h}$

To determine the depth of interest (h)

$t_{h}-A_{o}=I_{a} \times h$

$h=\frac{t_{h}-A_{o}}{I_{a}}$

$h=\frac{t_{h}-A_{o}}{I}$

Ia = Average geothermal gradient, $\mathrm{I}=$ Geothermal gradient, Ao = Mean annual surface temperature

th $=$ Temperature at depth of interest, $h=$ Depth of interest,

\section{Results and discussion}

The results for estimated geothermal gradients, temperatures at depth of interest shown in tables (2-6).

Table 2: The Results for Estimated Temperature Values for Shale Bed in Well 1

\begin{tabular}{llllll}
\hline S/N & $\begin{array}{l}\text { Depth (h) } \\
(\mathrm{ft})\end{array}$ & $\begin{array}{l}\text { Depth }(\mathrm{h}) \\
(\mathrm{m})\end{array}$ & Shale thickness (m) & $\begin{array}{l}\text { Geothermal gradient (I) } \\
\text { 0C/m }\end{array}$ & $\begin{array}{l}\text { Mean annual sur- } \\
\text { face temp. } \\
\text { 0C }\end{array}$ \\
\hline 1 & $9400-9640$ & $2814-2886$ & 72 & 0.028 & 22.00 \\
2 & $9680-9760$ & $2898-2922$ & 24 & 0.028 & 101.80 \\
3 & $10520-10560$ & $3150-3162$ & 12 & 0.028 & 103.48 \\
interest (th) m & 110.36 & 22.00 \\
\hline
\end{tabular}

Table 3: Temperature Results for Shale Bed in Well 2

\begin{tabular}{llllll}
\hline S/N & $\begin{array}{l}\text { Depth (h) } \\
\text { (ft) }\end{array}$ & $\begin{array}{l}\text { Depth (h) } \\
(\mathrm{m})\end{array}$ & Shale thickness (m) & $\begin{array}{l}\text { Geothermal gradient (I) } \\
\text { 0C/m }\end{array}$ & $\begin{array}{l}\text { Mean annual sur- } \\
\text { face temp. } \\
\text { 0C }\end{array}$ \\
\hline 1 & $9800-10120$ & $2934-3030$ & 96 & 0.028 & $\begin{array}{l}\text { Temp. at depth of } \\
\text { interest (th) } \mathrm{m}\end{array}$ \\
2 & $10120-10200$ & $3030-3054$ & 24 & 0.028 & 105.49 \\
3 & $10280-10320$ & $3078-3090$ & 12 & 0.028 & 22.00 \\
4 & $10460-10580$ & $3132-3168$ & 36 & 0.028 & 22.00 \\
5 & $10880-10960$ & $3257-3281$ & 24 & 0.028 & 22.00 \\
6 & $11400-11520$ & $3413-3449$ & 36 & 0.028 & 100 \\
\hline
\end{tabular}


Table 4: Temperature Results for Shale Bed in Well 3

\begin{tabular}{|c|c|c|c|c|c|c|}
\hline $\mathrm{S} / \mathrm{N}$ & $\begin{array}{l}\text { Depth (h) } \\
\text { (ft) }\end{array}$ & $\begin{array}{l}\text { Depth (h) } \\
(\mathrm{m})\end{array}$ & Shale thickness (m) & $\begin{array}{l}\text { Geothermal gradient (I) } \\
{ }^{0} \mathrm{C} / \mathrm{m}\end{array}$ & $\begin{array}{l}\text { Mean annual } \\
\text { surface temp. } \\
{ }^{0} \mathrm{C}\end{array}$ & $\begin{array}{l}\text { Temp. at depth } \\
\text { of interest }\left(t_{h}\right) m\end{array}$ \\
\hline 1 & $9800-10120$ & $2934-3030$ & 96 & 0.28 & 22.00 & 105.49 \\
\hline 2 & $10120-10200$ & $3030-3054$ & 24 & 0.28 & 22.00 & 107.17 \\
\hline 3 & $10280-10320$ & $3078-3090$ & 12 & 0.28 & 22.00 & 108.35 \\
\hline 4 & $10460-10580$ & $3132-3168$ & 36 & 0.28 & 22.00 & 110.20 \\
\hline 5 & $10880-10960$ & $3257-3281$ & 24 & 0.28 & 22.00 & 113.44 \\
\hline 6 & $11400-11520$ & $3413-3449$ & 36 & 0.28 & 22.00 & 118.06 \\
\hline
\end{tabular}

Table 5: Calculated Temperature Values for Shale Bed in Well 4

\begin{tabular}{|c|c|c|c|c|c|c|}
\hline $\mathrm{S} / \mathrm{N}$ & $\begin{array}{l}\text { Depth (h) } \\
\text { (ft) }\end{array}$ & $\begin{array}{l}\text { Depth (h) } \\
(\mathrm{m})\end{array}$ & $\begin{array}{l}\text { Shale thickness } \\
\text { (m) }\end{array}$ & $\begin{array}{l}\text { Geothermal gradient (I) } \\
{ }^{0} \mathrm{C} / \mathrm{m}\end{array}$ & $\begin{array}{l}\text { Mean annual surface } \\
\text { temp. } \\
{ }^{0} \mathrm{C}\end{array}$ & $\begin{array}{l}\text { Temp. at depth of interest }\left(\mathrm{t}_{\mathrm{h}}\right) \\
\mathrm{m}\end{array}$ \\
\hline $\begin{array}{l}1 \\
2 \\
3 \\
4 \\
5 \\
6\end{array}$ & $\begin{array}{l}10160- \\
10240 \\
10500- \\
10580 \\
10620- \\
10660 \\
10960- \\
10840 \\
11320- \\
11350 \\
11760- \\
11860\end{array}$ & $\begin{array}{l}3030- \\
3066 \\
3143- \\
3168 \\
3180- \\
3192 \\
3221- \\
3245 \\
3389- \\
3398 \\
3521- \\
3551\end{array}$ & $\begin{array}{l}36 \\
25 \\
12 \\
24 \\
10 \\
30\end{array}$ & $\begin{array}{l}0.29 \\
0.29 \\
0.29 \\
0.29 \\
0.29 \\
0.29\end{array}$ & $\begin{array}{l}21.90 \\
21.90 \\
21.90 \\
21.90 \\
21.90 \\
21.90\end{array}$ & $\begin{array}{l}110.29 \\
113.40 \\
114.29 \\
115.65 \\
120.31 \\
120.49\end{array}$ \\
\hline
\end{tabular}

Table 6: Computed Values for the Linear Model

\begin{tabular}{llll}
\hline $\mathrm{t}_{\mathrm{h}}^{0} \mathrm{C}$ & $60{ }^{0} \mathrm{C}$ & $120^{0} \mathrm{C}$ & $225{ }^{0} \mathrm{C}$ \\
\hline $\mathrm{h}(\mathrm{m})$ & & $3500 \mathrm{~m}$ \\
$h=\frac{t_{h}-A_{o}}{I_{a}}$ & $1357 \mathrm{~m}$ & $7250 \mathrm{~m}$ \\
\hline
\end{tabular}

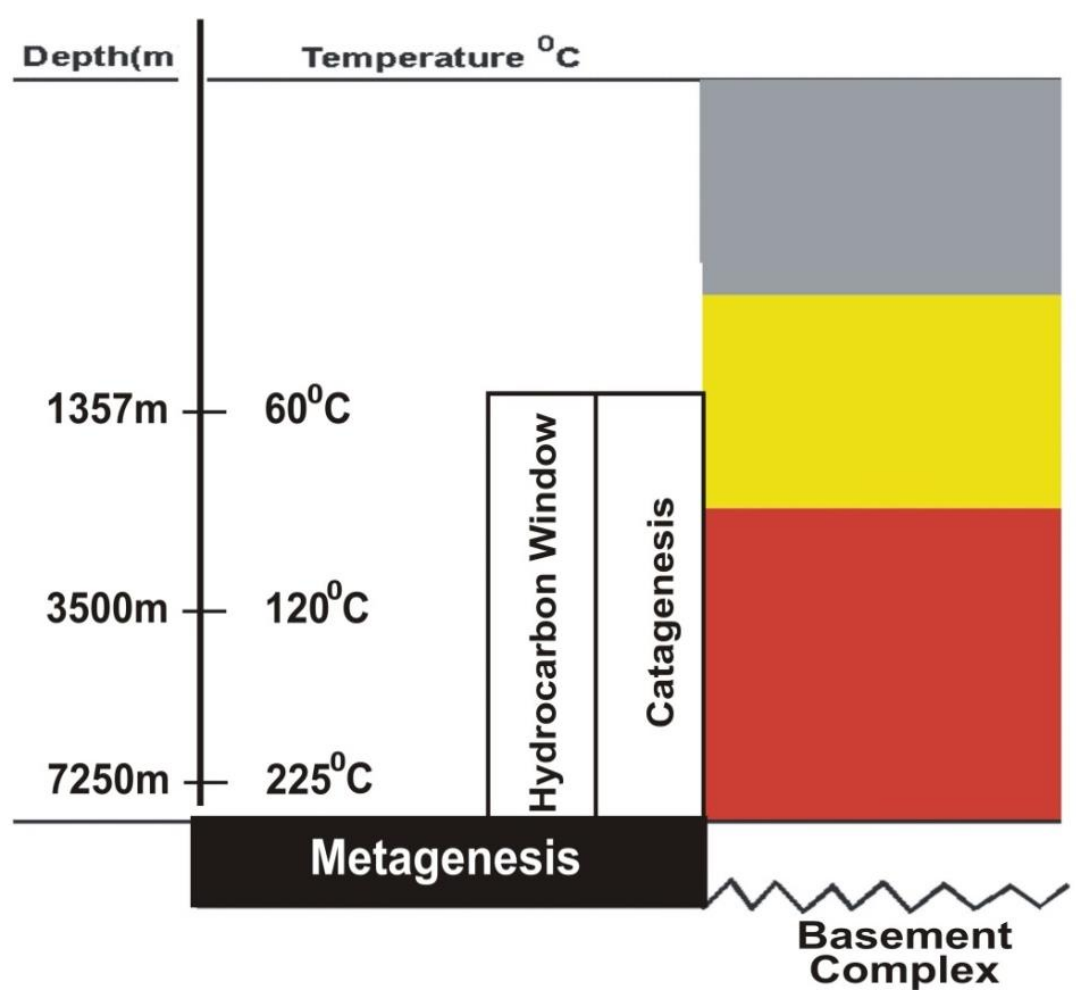

\section{Legend}

Benin Formation

Agbada Formation

Akata Formation
Catagenesis, Metagenesis and Hydrocarbon window of the field From the plot of formation temperature against formation depth, a linear model was generated. This linear model was used in the estimation of thickness, geothermal gradient and temperature's values for the field. This model was used to estimate the thick- nesses/depths of the formation that house the hydrocarbon in the field from 1357m-3500m (Fig.5 and Table.6).

The Agbada Formation thickness range in the Niger Delta Basin is from about $2000 \mathrm{~m}$ to $4000 \mathrm{~m}$ (Short and Stauble, 1967). The estimated thickness of $1357-3500 \mathrm{~m}$ in this study fall within the range of Short and Stauble (1967). The calculated geothermal gradient 
values and temperature values of Agbada Formation in the southern offshore parts of Niger Delta Basin calculated by Avbovbo (1978) were $3.3-4.7^{\circ} \mathrm{C} / 100 \mathrm{~m}$ and $\left(105^{\circ} \mathrm{C}-119^{\circ} \mathrm{C}\right)$ respectively. The estimated geothermal gradient of $\left(0.03^{\circ} \mathrm{C} / \mathrm{M}\right)$ and temperature values $101^{\circ} \mathrm{C}-120.5^{\circ}$ Crespectively in this study fall within the range of Avbovbo (1978). Evamy ET. al. (1978) estimated the temperature range of the Agbada shale bed of the study field for hydrocarbon generation to be $115^{\circ} \mathrm{C}-118^{\circ} \mathrm{C}$ in southern Niger Delta Basin, Nigeria and position the hydrocarbonwindow to be about $115^{\circ} \mathrm{C}$. This study was able to position the hydrocarbon window at about $101{ }^{\circ} \mathrm{C}-120^{\circ} \mathrm{C}$, which fall on the range of ( Evamy et. al.,1978, Avbovbo, 1978). (Selley, 1992, Akpononu et. al., 2012, Aigbadion et.al., 2016) stated that hydrocarbon generation for any sedimentary basins begins at $60^{\circ} \mathrm{C}$ and stops at $120^{\circ}$ C. The temperature model for the study starts above $50^{\circ} \mathrm{C}$ and ends at $225^{\circ} \mathrm{C}$ and my temperature's values falls within the range of Evamy ET. al. (1978). Odumudu (2009) estimated the offshore depobelt, mean annual surface temperature to about $22{ }^{\circ} \mathrm{C}$ and my estimated mean annual temperature values $\left(21.90-22^{\circ} \mathrm{C}\right)$ falls within the range of Odumudu (2009). It is important to note that temperature and thicknesses/ depth are important factors for geothermal modelling and flow simulation model. From all indication the thermal analysis showed that the Usani shale beds are thermally matured, oil and gas generation starts at $60^{\circ} \mathrm{C}-120^{\circ} \mathrm{C}$ and ends at $120^{\circ} \mathrm{C}-220^{\circ} \mathrm{C}$ respectively in the Usani field. The study also, show that the basal part of the Agbada shales are responsible for the expulsion of the hydrocarbon from the field and this support the work of Lambert-Alkhionbare and Ibe (1982), LambertAlkhionbare (1981). The hydrocarbon generation starts from $1357 \mathrm{~m}$ and ends at $3500 \mathrm{~m}$ in the study field.

\section{Conclusion}

The generated linear model was used to compliment source rock evaluation by determining thermal maturity of Usani shale beds of the Agbada Formation, and that is thermally mature and is the source rock of the Usani field, Niger Delta Basin. The earlier believe that the shale bed of the Agbada Formation is immature and cannot generate hydrocarbon is invalidated by this model. The model was also used to position the hydrocarbon window in the field.

\section{Acknowledgement}

The authors are thankful to the Director, Department of Petroleum Resources, Porth Harcourt, Nigeria for the provision of the data and the space to carry out this research.

\section{References}

[1] Aigbadon, G. O., Okoro, A.U. C.O., Una,Ocheli, A. (2017). Depositional facies model and reservoir characterization of Usani Field 1, Niger Delta Basin, Nigeria. International Journal of Advance Geosciences, 5 (2):57-68. https://doi.org/10.14419/ijag.v5i2.7720.

[2] Aigbadon, G.O., Okoro, A.U., Akpunonu, E.O., Orajaka, I. P. Ogunleye, C.O. (2016). The application of mathematical model for geo-temperature and hydrocarbon generation of Angalelei on shore field, Niger Delta Basin, Nigeria. Nigerian Journal of Applied Sciences, (34):70-78.

[3] Akpunonu, E.O., Okoro, A.U. Onuigbo, E.N. (2012). Hydrocarbon generative windows determination using geo mathematical model Case study from Ogbogede field, Niger Delta, Nigeria. J. Natural Sci. Research, 5 (2): 14.

[4] Avbovbo, A.A. (1978). Tertiary lithostratigraphy of Niger Delta. AAPG Bull., (62):293-300.

[5] Avbovbo, A. A (1978). Geothermal gradients in southern Niger Delta Basin, Bull.,Canadian Petrol. Geol., .3 (2): 268-274.

[6] Domkens, E.(1974). Lithofacies relations in the late quaternary $\mathrm{Ni}$ ger Delta Complex, AAPG Bull., (21) :195-222.

[7] Doust, H. and Omatsola, M. E. (1990). Divergent passive margin basins. AAPG. Mem.48, 201-238.
[8] Ejedawe, J.R. (1982). Pattern of incidence of oil reserves in Niger Delta Basin. AAPG Bull., (65):1574-1585.

[9] Ekweozor, C.M. and Daukoru, E.M. (1984). Petroleum source beds evaluation of the tertiary Niger Delta. AAPG Bull., (68) :390-394.

[10] Evamy, D.D., Haremeboure, J. Kamierling, W.A. Knaap, W.A. Molly and Rowland, P.H. (1978). Hydrocarbon Habitats of Tertiary Niger Delta, AAPG Bull., (62):1-39.

[11] Hyne N.J. (1984). Geology for Petroleum Exploration, Drilling and Production. New York, Mc Graw-Hill.

[12] Lambert-Alkhionbare, D.O. and Ibe, A.C.(1982). Petroleum source bed evaluation of tertiary Niger Delta. AAPG Bull., (.68):387-394.

[13] Lambert-Alkhionbare,D.O. (1981). The Agbada shales as source rocks for the Niger Delta Petroleum. Abstract of proceedings 10th Annual Conference. Nigerian Min.and Geosci.Soc., Lagos.180- 202

[14] Nwachukwu, J. I. and Chukwurah, P.I. (1986). Organic matter of Agbada Formation, Niger Delta Basin, Nigeria. AAPG Bull., (70):48-45.

[15] Odumodu, C.F.R. (2009). Subsurface temperature, geothermal gradients and hydrocarbon studies in the Calabar Flank. Global J. of Geol. Sci. (7):55 - 65.

[16] Selley R.C. (1996). Elements of Petroleum Geology, New York, Freeman. 449.

[17] Short K.C. and Stauble. A.J. (1965). Outline of Geology of the Niger Delta. AAPG bull.62, 761-779.

[18] Weber, K.J. (1971). Sedimentological aspects of oil fields in the Niger Delta; Geol. Magazine (50):554-576.

[19] Weber, K.J. and Daukoru, E.M. (1975). Petroleum geology ofNiger Delta. 9th World Petroleum Congress. (2):209-221. 